and persecuting spirit as has been displayed in the outrageous case of $\mathrm{Mr}$. Lamont-an outrage which will surely result in placing the medical man beyond the reach of being dismissed for reasons entirely independent of his doing his duty faithfully to the poor by securing him an appeal to the Local Government Board.

But I would venture to suggest another form of protection against arbitrary dismissal from local pique and local partisanship and, it may be, sectarian strife and religious rancour. In widespread counties, such as Inverness, Argyle, and Ross, it is absolutely necessary for the county medical officer of health to have provided for him local help. This help bas, of course, to be paid for by the different districts into which these counties have been divided, and these district medical officers are, of course, appointed and salaried by the district committees who are the local authorities, one half or thereby of these salaries Being contributed by Government under certain Acts of Parliament.

The remedy I have to offer is that these appointments should be carefully made, the holders properly remunerated by special grants, say, from the Scotch Congested District Board, and the holders be the servants of the district committee bursing the small allowances of which, and which alone (under the ordinary scale of payment for Poor-law attendances), the parish councils could claim to deprive their Poor-law medical officers. In other words, these men would become officiers de santé, as in France, be a part of the large army of sanitarians, and their duties would be directly to combat and if possiole prevent, the entrance of disease in their respective parishes and jurisdictions.

In this way, besides the advantages to themselves, they would be the servants of the public at large and be much more directly under the ægis of the Scottish Local Government Board. Again, I would hope to see the day when every such officer should have the advantage of a cottage hospital, mainly for the segregation and treatment of infectious diseases, but also when not so employed available for the care and comfort of many surgical and other diseases which meanwhile are allowed to go to the bad for the want of nursing and convenient medical skill and attention. But this question of isolation hospitals in remote districts is one which I would like to dilate upon at greater length than I would myself care to inflict upon your readers at this time. On another occasion if you will allow me I shall have more to say, unless, indeed, THE LANCET in its large-heartedness, shown on many previous occasions, will issue a commission to inquire into the whole problem of medical help in the Highlands of Scotland.

Dingwall, Nov. 6th, 1899. I am, Sirs, yours faithfully,

WilliaM BRUCE.

\section{"THE PREVENTION OF ALCOHOLISM."}

\section{To the Editors of THE LANCET.}

SIRI,-Mr. Vines says "Dr. Reid would saddle me with the task of confounding this thesis." $\mathrm{He}$ is unaccountably mistaken. I stated distinctly I had little expectation he would make the attempt and gave my reasons. It appears I was right. Moreover, I do not quite see what I am to gain by a controversy with $\mathrm{Mr}$. Vines. The subject is an abstruse, scientific one, with which, as I had already surmised and as he now admits, he is not competent to deal. For the sake of argument, as I expressly stated, I conceded Mr. Vines's point and invited him to deal with my main thesis-" if artificial selection be impracticable then the only alternative is natural selection, in which case every scheme for the promotion of temperance which depends on the diminution or abolition of the alcoholic supply is in effect a scheme for the promotion of ultimate drunkenness." I anticipated his reply with a good deal of interest, for, as I said, I have had some past experience, which bis refusal amusingly confirms. As I anticipated, he declines. He professes himself delighted with a concession purely verbal. At least be is easily satisfied. He thinks an essay which proves, beyond his powers of disproving, that the whole temperance policy is an enormous blunder which can lead to increased drunkenness only "was but to deliver a sermon barren of any result save the enlightenment of a benighted profession concerning a matter merely controversial," and in which, as he says, I was "pleased to deem the realm of practical politics of small account compared with the bogey of science for science' sake." Readers of my article will judge how gross is this queer misrepresentation if it be intentional, how wonderful the lack of comprehension if it be not. It would be interesting to learn what kind of essay has a human interest in Mr. Vines's opinion-one in which personal insinuations take the place of facts and arguments? He says that even had he the ability he has not the desire to controvert my main thesis and he professes himself content. For an ardent temperance reformer, boasting of common sense, he certainly is the most easily contented person I ever heard of. Surely it will be deemed significant if an attack on the whole temperance policy in the leading medical journal elicits no defence more serious than little insinuations of Mr. Vines, his strategic retreat, and his amazing satisfaction.

Once more, if artificial selection be impracticable then the only alternative is natural selection. In my opinion artificial selection is right and given an educated public it is practicable. It can be combined with temperance reform, for while safeguarding the species we may endeavour to reform the individual. But all this, dealing as it does with questions of ethics, of votes, and of education, is a mere opinion. It is not a question of science. If, however, opponents disagree and declare with $\mathrm{Mr}$. Vines that artificial selection is neither right nor practicable, then if it is worth their while to deal with me at all they are on the horns of a dilemma. Either they must find the weak link in my argument or they must advocate unlimited drunkenness.

Southsea, Nov. 7th, 1899

$$
\text { I am, Sirs, yours faithfully, }
$$

$$
\text { G. ARchdall Reid. }
$$

\section{To the Editors of THE LANCET.}

Srrs, - A paper by Dr. Archdall Reid in The LANCET of Oct. 14th on the relation between alcoholism and heredity has given rise to some discussion both among medical men and in the temperance press. Dr. Reid's point of view is not that usually taken up by exponents of this subject. For him a parent's drunken habits carry with them no fear that his children will probably be thereby weakened against the temptation to like indulgence. Acquired characters impressed upon nerve or other cells by the habits of an individual, he tells us, are not proved to be transmissible. On the other hand, variations produced in the germ-cell prior to its intra-uterine development, such as family resemblance, for example, are transmitted. The habit of temperance be regards as merely an inborn peculiarity rather than a re lt of moral self-restraint and education.

Similarly the existence of a relatively temperate class or nation means for him a result of an evolution which in course of time has weeded out intemperate members from such a community. On this hypothesis he explains the comparative abstinence of some peoples and the still prevalent liability to excess among others. He admits, however, that there is such a thing as an inborn and transmissible capability of enjoying alcohol, but the taste of drink is necessary to develop this. He further allows that drinking tends to increase this capability, in some persons more, in others less. These admissions do not, however, appear to him sufficient to justify a belief in the transmissibility of the craving for drink. He consequently sees no occasion to attempt the restraint of drunkenness by the ordinary processes of temperance reform. He does not, indeed, propose to leave man entirely in the hands of nature and let him extinguish himself with his habits by unlimited indulgence. He would prefer to extirpate drunkenness by prohibiting and penalising reproduction among the intemperate. But reform he holds to be worse than useless and as tending only to perpetuate the evil by preserving a class of persons naturally prone to excess. Dr. Reid's obserrations, as I have stated, have not been allowed to pass unchallenged. Dr. Sims Woodhear compares his views to those of one who would encourage the extension of typhus fever (now nearly extinguished by preventive measures) in order to secure a costly immunity in accordance with the law of the survival of the fittest Mr. Walter Edwards, writing in the Temperance Record, quotes the desire for knowledge in the children of educated parents as combating his views on heredity, and he furtber disputes his assertion that drunkenness is now least prevalent among the formerly drunken races. I must admit that in my opinion Dr. Reid's argument, though intricate and ingenious, appears to take too much for granted. The proofs of hereditary transmission have not perhaps been marshalled in this connexion with statistical accuracy. Nevertheless, what 
evidence we have is strongly suggestive of their existence, while examples of transmitted aptitudes, which are undoubtedly asquirements as much as variations in the sense intended by Dr. Reid, are innumerable. Moreover, if, as he asserts, the "capacity for enjoying alcohol is inborn and transmissible," and this capacity is increased by exercise within " limits which vary immensely," there seems no just reason to doubt that a capacity so increased, it may be through successive generations, is transmissible in its augmented measure. As for the cure by evolution or that by Malthusian extirpation, they may be philosophical, but it can hardly be doubted that in no state of human society would either be found to be practicable. On the other hand, it is certainly begging the question to describe that reasonable self-denial which is the logical contrary of alcoholic indulgence as a "temperance fallacy."

Nov. 4th, 1899 I am, Sirs, yours faithfully, B. G. Morison.

\section{"INFANT FOODS AND SCURVY RICKETS." To the Editors of THE LANCET.}

SIRS,-In a letter on this subject in THE LANCET of Nov. 4th (p. 1256) Dr. Ransom describes two striking cases of scurvy rickets caused by the use of a certain "infant's food." With his subsequent remarks on the dangers of these foods I think all who have studied the subject will be in agreement, but his final paragraph appears to undo the good effect which his previous sentences might have produced. In it he expresses a desire that the makers of these foods " should add to their value and diminish their danger by issuing with their tins a caution as to the need for the addition of some fresh food substance to the dietary." This would seem to imply that if a notice to the above effect is attached then the food may be used as a safe diet for infants. A glance at the advertisement columns of THE LANCET will show that a notice of this nature had already been issued by the makers.

But, Sirs, I do not think that this meets the case. In connexion with the sale of poisons the law insists that a printed notice must be affixed as to their poisonous nature. In the case of infant foods Dr. Ransom would suggest, not that their harmful nature should be stated, but that a notice should be attached describing the antidote which must be take to prevent any ill-effects. Experience has shown that such a notice, which would of course appear in small type, would seldom be read and probably never acted on. Even if it were acted on it is open to grave question whether the result would be satisfactory; and I observe that Dr. Ransom's own practice in the cases which he records is not to continue the patent food with the addition of the antidote but to change the diet entirely to one of fresh milk, \&c. On the principle that prevention is better than cure, and in the present state of our knowledge, the only safe course to pursue seems to be to abolish these foods entirely from the dietary of young infants except under medical advice. The uses and limitations of these patent infant foods have been well described in a recent annotation in THE LANCE' ${ }^{1}{ }^{1}$, which probably also expresses Dr. Ransom's own views on the subject, but his remark quoted above appears capable of an interpretation which might lead to unfortunate results.

$$
\text { I am, Sirs, yours faithfully, }
$$

Old Cavendish-street, W., Nov. 6th, 1899

$$
\text { G. A. SUTHERLAND. }
$$

\section{To the Editors of THE LANCET.}

SIRs,-In reference to my letter on this subject in THE LANCET of Nov. 4th Messrs. Allen and Hanburys have written to me to point out that their more recent advertisements do contain a caution against the prolonged exclusive use of their preparations without the addition of some fresh food substance. I am very glad to find that this is so and to acknowledge the desire of the firm to supply a sound article. The object of my letter was not to specially criticise the "Allenburys" foods, but to emphasise the lesson taught by MM. Guinon and Le Guelland in the paper mentioned in an annotation in THE LANCE' of Oct. 28th that the prolonged use of even the most (chemically) perfect foods, which have been subjected to thorough sterilisation, is attended with the risk of scurvy rickets. Whether it be "maternised milk"

1 The Lafcet, Oct. 28th, 1899, p. 1181. or "infants' food" the purchaser ought to find on the bottle or tin full instructions as to how to avoid this danger.

Nottingham, Nov. 6th, 1899

I am, Sirs, yours faithfully,

W. B. RANSOM.

\section{VACCINATION STATISTICS: A QUESTION OF ARITHMETIC.}

To the Editors of THE LANCET.

SrRs,-You are aware, and are doubtless proud to be aware. that THE LANCET is read not only by the medical profession but by a large number of educated laymen. Also, that in the present day there are constantly arising among the sub. jects of treatment in THE LANCET questions of political and statistical importance on which the views of laymen may be competently expressed and may fairly be accorded a respectful reception in your columns. There is an impression, however, among some of my friends that if $I$, a layman, desire, however respectfully, to place before you, for the candid consideration of the profession, a fair criticism of certain medical statistics your columns will not be opened to me-that you will deem the tendency of my criticism to be mischievous the moment you discover that it relates to small-pox and vaccination. I take leave to doubt this and I write to you boldly in the confidence that you will treat this communication on its merits and without regard to the question whether or not it seems to weaken one of the arguments for vaccination. If it does, all the more reason for its careful consideration; if not, it can be promptly disposed of and no harm done. I make my appeal for a hearing first to the scientific instincts of your profession and secondly to their chivalrous instincts. The appeal to their chivalry is based on the fact that the law of compulsory vaccination is upheld entirely by medical sanction-a fact which places medical men under a special obligation to hold their minds open to any criticism. The appeal to the scientific spirit I need not defend. No true man of science contests the duty of submitting his conclusions to the test of criticism.

I am desirous to illustrate a fallacy in the medical statistics of vaccination by reference to Dr. Coupland's report to the Royal Commission on the Gloucester epidemic (Appendix VII. to the Final Report). Dr. Coupland's statistics with regard to certain invaded houses deal with a community of 4861 persons exposed to infection, of whom 1717 were attacked with small-pox. This is an attack-rate of nearly $35 \frac{1}{2}$ per cent. But subdividing this community into (1) those vaccinated, (2) those undergoing vaccination "just before or during the invasion of their homes by small-pox," and (3) those not vaccinated, Dr. Coupland arrives at the conclusion that "the attack-rates are inversely to the proportionate numbers exposed to infection, being as much lower amongst the vaccinated as they are higher amongst the unvaccinated." He made the discovery of these "singular results" in the course of an analysis of the cases in four groups, an analysis undertaken for the purpose of determining the effect of hospital isolation in limiting the spread of the disease, and I am obliged to correct his totals because they are derived by taking the mean of his four percentages. You cannot, of course, get correct averages of percentages in this way. You must go back to the figures on which your percentages are based, sum them up, and take fresh percentages. According to this reckoning Dr. Coupland's point is represented by the following figures :-

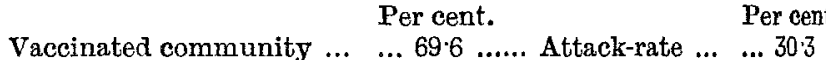

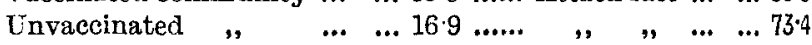

This undoubtedly is a very impressive demonstration. What I want to ask is whether it is scientific.

It will be observed that about $13 \frac{1}{2}$ per cent. of the com munity under consideration are not at present accounted for. This $13 \frac{1}{2}$ per cent. is represented by the proportion of the community treated as "undergoing vaccination" and curiously enough, their attack-rate was nearly equivalent to their proportion of the community : it was 13 per cent. From that fact I start my criticism. Assuming 14 days to be the period that must elapse before those "undergoing vaccination" can be passed into the vaccinated class we have it here established that for the purposes of these statistics the community suffering at the very small attack-rate of 13 per cent. have been withdrawn within a fortnight 